\title{
UPAYA HUKUM PENINJAUAN KEMBALI DALAM PERKARA PIDANA PASCA PUTUSAN MAHKAMAH KONSTITUSI
}

\author{
REMEDY REVIEW OF CRIMINAL CASE AFTER CONSTITUTIONAL COURT RULING
}

\author{
Ani Triwati, Subaidah Ratna Juita, Tri Mulyani \\ Fakultas Hukum \\ Unversitas semarang
}

\begin{abstract}
ABSTRAK
Dengan adanya Putusan MK No. 34/PUU-XI/2013, untuk upaya hukum luar biasa yaitu peninjauan kembali dapat dilakukan lebih dari satu kali. Putusan MK yang memperbolehkan upaya hukum luar biasa peninjauan kembali lebih dari satu kali tersebut, berkaitan dengan kepastian hukum dan keadilan. Apabila peninjauan kembali diperbolehkan lebih dari satu kali tetapi tidak ada pembatasan sampai berapa kali maka perkara tersebut tidak akan ada akhirnya, bahwa adanya asas litis finiri oportet (setiap perkara harus ada akhirnya) tidak akan terpenuhi. Beberapa permasalahan yang perlu dibahas adalah apakah dengan adanya Putusan MK No. 34/PUU-XI/2013 dapat memenuhi nilai keadilan dan kepastian hukum. Selanjutnya bagaimana pengaturan mengenai peninjauan kembali sebagai implementasi Putusan MK No. 34/PUU$\mathrm{XI} / 2013$ agar asas kepastian hukum dan asas litis finiri oportet akan terpenuhi. Putusan MK No. 34/PUUXI/2013, yang menyatakan bahwa Pasal 268 ayat (3) Undang-Undang Nomor 8 Tahun 1981 tentang Hukum Acara Pidana bertentangan dengan Undang-Undang Dasar Negara Republik Indonesia tahun 1945 dan tidak mempunyai kekuatan mengikat, dapat memenuhi kepastian hukum tanpa mengabaikan nilai keadilan. Hal ini dapat dilihat dari pihak kepentingan terpidana yang mana dengan diperbolehkannya peninjauan kembali dalam perkara pidana lebih dari satu kali, memberikan kesempatan untuk memperoleh kebenaran materiil dan keadilan sehingga dapat diperoleh kepastian hukum yang berkeadilan bagi terpidana mengenai perkara yang dihadapi. Untuk memenuhi asas litis finiri oportet, perlu dilakukan pengaturan bahwa untuk upaya hukum peninjauan kembali dalam perkara pidana dapat dilakukan dua kali, hal ini dilakukan untuk mencapai kepastian hukum yang berkeadilan. Di satu pihak peninjauan kembali dapat dilakukan lebih dari satu kali untuk mencari kebenaran materiil dan memenuhi nilai keadilan. Di lain pihak adanya pembatasan permohonan peninjauan kembali yang boleh dilakukan dua kali adalah untuk menjamin kepastian hukum, sehingga nilai kemanfaatan, keadilan dan kepastian hukum dapat terpenuhi.
\end{abstract}

Kata Kunci : upaya hukum, pidana, peninjauan kembali.

\section{ABSTRACT}

With the Constitutional Court No. 34 / PUU-XI / 2013, for an extraordinary legal remedy which reconsideration can be done more than once. Constitutional Court ruling that allows an extraordinary legal remedy reconsideration more than once that, with regard to legal certainty and justice. If allowed to review more than one time but there are no restrictions on how many times it is the case there will be no end, that the principle of litis finiri oportet (every case there should be eventually) will not be met. Some issues that need to be addressed is whether the Constitutional Court No. 34 / PUU-XI / 2013 can satisfy the value of justice and legal certainty. Furthermore, how the arrangements regarding the review of the implementation of the Constitutional Court as No. 34 / PUU-X/2013 that the principle of legal certainty and the principle of litis finiri oportet will be met. Constitutional Court decision No. 34 / PUU-XI / 2013, which states that Article 268 paragraph (3) of Law No. 8 of 1981 on Criminal Procedure is contrary to the Constitution of the Republic of Indonesia in 1945 and has no binding force, can meet the legal certainty without ignoring the value of justice. It can be seen from the interests of the convict which the permissibility of judicial review in criminal cases more than once, providing an opportunity to acquire the material truth and justice so as to obtain legal certainty to convict justice regarding the case at hand. To meet the principle of litis finiri oportet, it is necessary that the arrangements for legal remedy reconsideration in criminal cases can be done twice, this is done to achieve a just rule of law. On the one hand, the review can be performed more than once to search for the material truth and fulfill justice values. On the other hand the restrictions on the 
reconsideration request should be done twice is to ensure legal certainty, so that the value of expediency, justice and the rule of law can be fulfilled.

Keywords: legal actions, criminal, reconsideration

\section{PENDAHULUAN}

\section{A. Latar Belakang Penelitian}

Penjatuhan pidana terhadap terdakwa yang terbukti secara sah dan meyakinkan melakukan tindak pidana, merupakan salah satu tujuan dari pemidanaan yaitu untuk memberikan efek jera bagi pelaku dan secara psikis memberikan efek pencegahan umum agar masyarakat tidak melakukan perbuatan yang dilarang undangundang. Dalam hukum acara pidana, kebenaran yang dicari dalam proses pemidanaan adalah kebenaran materiil yaitu kebenaran yang sesungguhnya. Kebenaran materiil dapat diperoleh meskipun proses pemeriksaan perkara pidana sudah selesai dan putusan hakim telah mempunyai kekuatan hukum tetap. Undang-undang telah mengatur upaya hukum yang dapat dilakukan, apabila terdakwa atau terpidana atau penuntut umum merasakan ketidakadilan dalam putusan hakim khususnya untuk putusan pemidanaan. Upaya hukum tersebut meliputi upaya hukum biasa yaitu banding dan kasasi, dan upaya hukum luar biasa yang meliputi kasasi demi kepentingan hukum dan peninjauan kembali.

Dalam penulisan ini, dikhususkan pada uji materi terhadap upaya hukum luar biasa peninjauan kembali yaitu terhadap Pasal 268 ayat (3) KUHAP yang diajukan oleh Antasari Azhar dan keluarganya (isteri dan anak dari Antasari Azhar). Antasari beralasan bahwa Pasal 268 ayat (3) KUHAP bertentangan dengan konstitusi yang telah menjamin hak warga negaranya untuk mendapatkan kepastian hukum. Dalam permohonannya, menurut Antasari Azhar bahwa Pasal 268 ayat (3) KUHAP bertentangan dengan Pasal 1 ayat (3), Pasal 24 ayat (1), Pasal 28A, Pasal 28C ayat (1) dan Pasal 28D ayat (1) UndangUndang Dasar Negara Republik Indonesia Tahun 1945 (untuk selanjutnya disebut UUD 1945), dengan menitikberatkan pada hak untuk mendapatkan manfaat dari ilmu pengetahuan dan teknologi sebagaimana dalam Pasal 28C ayat (1) UUD 1945.

Pengujian Pasal 268 ayat (3) KUHAP tersebut telah diputus MK dengan Putusan No. 34/PUU$\mathrm{XI} / 2013$ yang menyatakan bahwa Pasal 268 ayat (3) Undang-Undang Nomor 8 Tahun 1981 tentang Hukum Acara Pidana (Lembaran Negara Republik Indonesia Tahun 1981 Nomor 76, Tambahan
Lembaran Negara Republik Indonesia nomor 3209) bertentangan dengan Undang-Undang Dasar Negara Republik Indonesia tahun 1945 dan tidak mempunyai kekuatan hukum mengikat. Dengan adanya Putusan MK No. 34/PUU-XI/2013 tersebut, dapat dikatakan bahwa untuk upaya hukum luar biasa yaitu peninjauan kembali dalam perkara pidana dapat dilakukan lebih dari satu kali, dapat dua kali, tiga kali atau lebih selama belum ada aturan hukum yang mengatur pembatasan sampai berapa kali dapat diajukan peninjauan kembali. Dengan demikian masih diperlukan pengaturan tersendiri sebagai pelaksanaan dari putusan MK tersebut agar kepastian hukum dan keadilan dapat terpenuhi.

\section{B. Rumusan Permasalahan}

Pasca Putusan MK No. 34/PUU-XI/2013, yang memperbolehkan peninjauan kembali lebih dari satu kali dalam perkara pidana, maka beberapa permasalahan yang perlu dibahas adalah :

1. Apakah dengan adanya Putusan MK No. 34/PUU-XI/2013 yang memperbolehkan peninjauan kembali lebih dari satu kali dalam perkara pidana dapat memenuhi nilai keadilan dan kepastian hukum?

2. Bagaimana pengaturan mengenai peninjauan kembali sebagai implementasi Putusan MK No. 34/PUU-XI/2013 agar asas kepastian hukum dan asas litis finiri oportet (setiap perkara harus ada akhirnya) akan terpenuhi?

\section{TINJAUAN PUSTAKA}

\section{A. Kewenangan Mahkamah Konstitusi}

Negara Indonesia adalah negara hukum, pernyataan tersebut terdapat dalam Pasal 1 ayat (3) Undang-Undang Dasar Negara Republik Indonesia Tahun 1945 (untuk selanjutnya disebut UUD 1945). Sebagai negara hukum, negara menjamin hak dan kewajiban warga negara di bidang hukum dalam konstitusi. Hak dan kewajiban warga negara, pengaturan mengenai legislatif, yudikatif dan eksekutif yang ada dalam konstitusi atau UUD 1945 diatur lebih lanjut dalam undang-undang. Apabila pengaturan dalam undang-undang tidak sesuai atau bertentangan dengan UUD 1945, maka dapat diajukan pengujian undang-undang tersebut terhadap UUD 1945 yang diajukan kepada 
Mahkamah Konstitusi. Hal ini sebagaimana diatur dalam Pasal 24C ayat (1) UUD 1945 yang menyatakan :

Mahkamah Konstitusi berwenang mengadili pada tingkat pertama dan terakhir yang putusannya bersifat final untuk menguji undang-undang terhadap Undang-Undang Dasar, memutus sengketa kewenangan lembaga negara yang kewenangannya diberikan oleh Undang-Undang Dasar, memutus pembubaran partai politik dan memutus perselisihan tentang hasil pemilihan umum.

Dari ketentuan Pasal 24C ayat (1) UUD 1945 tersebut jelas bahwa Mahkamah Konstitusi (MK) mempunyai kewenangan untuk menguji undangundang terhadap undang-undang dasar (UUD 1945), memutus sengketa kewenangan lembaga negara yang kewenangannya diberikan oleh undang-undang dasar, selanjutnya juga memutus pembubaran partai politik dan memutus perselisihan tentang hasil pemilihan umum. Dari kewenangan tersebut dapat dilihat bahwa Mahkamah Konstitusi juga merupakan pemegang dari kekuasaan kehakiman, sebagaimana dinyatakan dalam Pasal 24 UUD 1945 yang menyebutkan :

(1) Kekuasaan Kehakiman merupakan kekuasaan yang merdeka untuk menyelenggarakan peradilan guna menegakkan hukum dan keadilan.

(2) Kekuasaan kehakiman dilakukan oleh sebuah Mahkamah Agung dan badan peradilan yang berada di bawahnya dalam lingkungan peradilan umum, lingkungan peradilan agama, lingkungan peradilan militer, lingkungan peradilan tata usaha negara, dan oleh sebuah Mahkamah Konstitusi.

Pengaturan lebih lanjut mengenai Mahkamah Konstitusi sebagai pelaku atau pemegang kekuasaan kehakiman dan mengenai kewenangan Mahkamah Konstitusi adalah dalam UndangUndang Nomor 24 Tahun 2003 tentang Mahkamah Konstitusi sebagaimana telah diubah dengan Undang-Undang Nomor 8 Tahun 2011 tentang Perubahan Atas Undang-Undang Nomor 24 Tahun 2003 tentang Mahkamah Konstitusi, dalam Pasal 1 butir 1 yang menyebutkan bahwa Mahkamah Konstitusi adalah salah satu pelaku kekuasaan kehakiman sebagaimana dimaksud dalam UndangUndang Dasar Negara Republik Indonesia Tahun 1945, dan Pasal 10 ayat (1) yang menyatakan:

(1) Mahkamah Konstitusi berwenang mengadili pada tingkat pertama dan terakhir yang putusannya bersifat final untuk: a. menguji undang-undang terhadap Undang-Undang Dasar Negara Republik Indonesia Tahun 1945;

b. memutus sengketa kewenangan lembaga negara yang kewenangannya diberikan oleh Undang-Undang Dasar Negara Republik Indonesia Tahun 1945;

c. memutus pembubaran partai politik; dan

d. memutus perselisihan tentang hasil pemilihan umum.

Dalam Undang-Undang No.48 Tahun 2009 tentang Kekuasaan Kehakiman, Pasal 1 butir 3 disebutkan bahwa Mahkamah Konstitusi adalah pelaku kekuasaan kehakiman sebagaimana dimaksud dalam Undang-Undang Dasar Negara Republik Indonesia Tahun 1945 dan dalam Pasal 18 yang menyebutkan bahwa kekuasaan kehakiman dilakukan oleh sebuah Mahkamah Agung dan badan peradilan yang berada di bawahnya dalam lingkungan peradilan umum, lingkungan peradilan agama, lingkungan peradilan militer, lingkungan peradilan tata usaha negara, dan oleh sebuah Mahkamah Konstitusi. Selanjutnya Pasal 29 ayat (1) menyebutkan bahwa Mahkamah Konstitusi berwenang mengadili pada tingkat pertama dan terakhir yang putusannya bersifat final untuk:

(1) menguji undang-undang terhadap UndangUndang Dasar Negara Republik Indonesia Tahun 1945;

(2) memutus sengketa kewenangan lembaga negara yang kewenangannya diberikan oleh Undang-Undang Dasar Negara Republik Indonesia Tahun 1945;

(3) memutus pembubaran partai politik;

(4) memutus perselisihan tentang hasil pemilihan umum dan;

(5) kewenangan lain yang diberikan oleh undangundang.

Undang-Undang Nomor 12 Tahun 2011 tentang Pembentukan Peraturan PerundangUndangan, Pasal 9 ayat (1) menyebutkan bahwa dalam hal undang-undang diduga bertentangan dengan Undang-Undang Dasar Negara Republik Indonesia Tahun 1945, pengujiannya dilakukan oleh Mahkamah Konstitusi.

\section{B. Upaya Hukum}

Upaya hukum dibagi menjadi dua yaitu upaya hukum biasa dan upaya hukum luar biasa. Upaya hukum biasa meliputi banding dan kasasi, sedangkan upaya hukum luar biasa meliputi kasasi demi kepentingan hukum dan peninjauan kembali. 


\section{B.1. Upaya Hukum Biasa B.1.1. Banding}

Upaya hukum banding diatur dalam $\mathrm{Bab}$ XVII Bagian Kesatu Pasal 233 sampai dengan Pasal 243 KUHAP. Dalam Pasal 67 KUHAP disebutkan bahwa terdakwa atau penuntut umum berhak untuk minta banding terhadap putusan pengadilan tingkat pertama kecuali terhadap putusan bebas, lepas dari segala tuntutan hukum yang menyangkut masalah kurang tepatnya penerapan hukum dan putusan pengadilan dalam acara cepat. Dari segi yuridis formal berdasarkan Pasal 67 KUHAP tersebut, upaya banding adalah hak yang dapat diminta oleh pihak yang berkepentingan (terdakwa atau penuntut umum) agar perkaranya diperiksa lagi dalam peradilan tingkat banding. Banding yaitu upaya hukum yang dapat diajukan baik oleh terdakwa maupun penuntut umum apabila merasa tidak puas terhadap putusan pengadilan tingkat I. ${ }^{1}$ Dapat dikatakan bahwa alasan untuk mengajukan banding adalah ketidakpuasan atau keberatan terhadap putusan pengadilan tingkat pertama.

Banding sebagaimana dalam Pasal 67 KUHAP, merupakan hak dari terdakwa atau penuntut umum, sehingga dapat dijelaskan sebagai berikut:

1) Terserah kepada terdakwa atau penuntut umum untuk mempergunakan dan memanfaatkan hak tersebut.

2) Apabila mereka mempergunakan hak banding "wajib diterima". Seandainya terdakwa atau penuntut umum mempergunakan hak banding, permintaan banding tersebut "wajib" diterima pengadilan, jika permintaan itu memenuhi syarat yang ditentukan undang-undang. ${ }^{2}$

Permohonan banding dilakukan dalam tenggang waktu 7 (tujuh) hari setelah putusan dijatuhkan atau setelah putusan diberitahuakan kepada terdakwa yang tidak hadir sebagaimana yang dimaksud Pasal 196 ayat (2) KUHAP yang menyatakan bahwa dalam hal terdapat lebih dari seorang terdakwa dalam satu perkara, putusan dapat diucapkan dengan hadirnya terdakwa yang ada.

Putusan pengadilan tingkat banding dapat berupa menguatkan atau mengubah atau

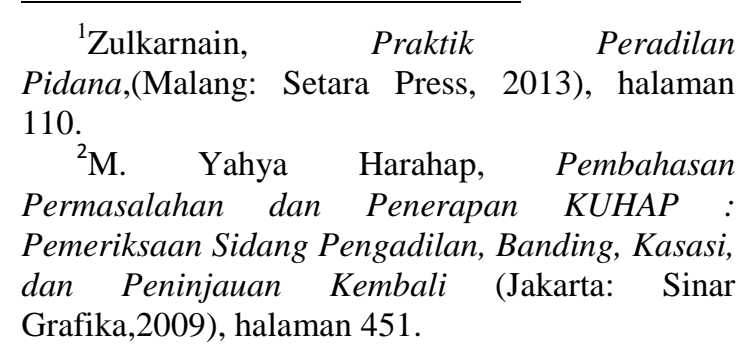

membatalkan putusan pengadilan negeri dan membuat keputusan sendiri, hal ini sebagaimana diatur dalam Pasal 241 KUHAP yang menyebutkan:

(1) Setelah semua hal sebagaimana dimaksud dalam ketentuan tersebut di atas dipertimbangkan dan dilaksanakan, pengadilan tinggi memutuskan, menguatkan atau mengubah atau dalam hal membatalkan putusan pengadilan negeri, pengadilan tinggi mengadakan putusan sendiri.

(2) Dalam hal pembatalan tersebut terjadi atas putusan pengadilan negeri karena ia tidak berwenang memeriksa perkara itu, maka berlaku ketentuan tersebut pada Pasal 148.

\section{B.1.2. Kasasi}

Upaya hukum kasasi diatur dalam Pasal 244 sampai dengan Pasal 258 KUHAP. Kasasi merupakan upaya hukum yang diajukan terdakwa atau penuntut umum apabila tidak puas terhadap putusan pengadian tingkat II, melalui pengadilan tingkat pertama (PN) yang mengadili perkara tersebut. ${ }^{3}$ Dalam Pasal 244 KUHAP disebutkan bahwa terhadap putusan perkara pidana yang diberikan pada tingkat terakhir oleh pengadilan lain selain daripada Mahkamah Agung, terdakwa atau penuntut umum dapat mengajukan permintaan pemeriksaan kasasi kepada Mahkamah Agung kecuali terhadap putusan bebas. Dengan demikian dapat dikatakan bahwa kasasi merupakan upaya hukum yang diajukan oleh terdakwa atau penuntut umum terhadap putusan pengadilan tingkat terakhir selain Mahkamah Agung.

Terhadap Pasal 244 KUHAP, telah diajukan uji materi ke MK dengan putusan Nomor 114/ PUU-X/2012, yang pada intinya menyebutkan:

1.1 Menyatakan frasa, "kecuali terhadap putusan bebas" dalam Pasal 244Undang-Undang Nomor 8 Tahun 1981 tentang Hukum Acara Pidana (Lembaran Negara Republik Indonesia Tahun 1981 Nomor 76, Tambahan Lembaran Negara Republik Indonesia Nomor 3209) bertentangan dengan Undang-Undang Dasar Negara Republik Indonesia Tahun 1945;

1.2 Menyatakan frasa, "kecuali terhadap putusan bebas" dalam Pasal 244 Undang-Undang Nomor 8 Tahun 1981 tentang Hukum Acara Pidana (Lembaran Negara Republik Indonesia Tahun 1981 Nomor 76,Tambahan Lembaran Negara Republik Indonesia Nomor 3209) tidak mempunyai kekuatan hukum mengikat; ${ }^{4}$

\footnotetext{
${ }^{3}$ Zulkarnain, op.cit., halaman 111.

${ }^{4}$ Putusan MK Nomor 114/PUU-X/2012.
} 
Untuk tenggang waktu permohonan kasasi berbeda dengan tenggang waktu permohonan banding. Tenggang waktu mengajukan kasasi adalah 14 hari sebagaimana diatur dalam Pasal 245 KUHAP yang menyatakan bahwa permohonan kasasi disampaikan oleh pemohon kepada panitera pengadilan yang telah memutus perkaranya dalam tingkat pertama, dalam waktu empat belas hari sesudah putusan pengadilan yang dimintakan kasasi itu diberitahukan kepada terdakwa.

Pemeriksaan kasasi merupakan pemeriksaan mengenai penerapan hukum, bukan pemeriksaan kembali terhadap fakta-fakta atau peristiwa yang telah diperiksa oleh pengadilan negeri maupun pengadilan tinggi. Alasan dari permohonan kasasi diatur dalam Pasal 253 ayat (1)KUHAP yang menyebutkan:

(1) Pemeriksaan dalam tingkat kasasi dilakukan oleh Mahkamah Agung atas permintaan para pihak sebagaimana dimaksud dalam Pasal 244 dan Pasal 248 guna menentukan :

a. apakah benar suatu peraturan hukum tidak diterapkan atau diterapkan tidak sebagaimana mestinya;

b. apakah benar cara mengadili tidak dilaksanakan menurut ketentuan undangundang;

c. apakah benar pengadilan telah melampaui batas wewenangnya.

Putusan mengenai kasasi, dapat menolak permohonan kasasi atau mengabulakn permohonan kasasi sebagaimana diatur dalam Pasal 254 KUHAP yang menyebutkan bahwa dalam hal Mahkamah Agung memeriksa permohonan kasasi karena telah memenuhi ketentuan sebagaimana dimaksud dalam Pasal 245, Pasal 246 dan Pasal 247, mengenai hukumnya Mahkamah Agung dapat memutus menolak atau mengabulkan permohonan kasasi.

\section{B.2. Upaya Hukum Luar Biasa}

\section{B.2.1. Kasasi demi Kepentingan Hukum}

Upaya hukum luar biasa diajukan terhadap putusan pengadilan yang telah berkekuatan hukum tetap. Kasasi demi kepentingan hukum diatur dalam Pasal 259 sampai Pasal 262 KUHAP. Kasasi demi kepentingan hukum diajukan terhadap semua putusan pengadilan kecuali terhadap putusan Mahkamah Agung dan hanya diajukan satu kali oleh jaksa agung, jadi terbatas pada putusan pengadilan negeri dan pengadilan tinggi. Hal ini diatur dalam Pasal 259 KUHAP yang menyebutkan:

(1) Demi kepentingan hukum terhadap semua putusan yang telah memperoleh kekuatan hukum tetap dari pengadilan lain selain daripada Mahkamah Agung, dapat diajukan satu kali permohonan kasasi oleh Jaksa Agung.

(2) Putusan kasasi demi kepentingan hukum tidak boleh merugikan pihak yang berkepentingan.

Yang berhak melakukan upaya hukum kasasi demi hukum hanya jaksa agung, terpidana tidak boleh mengajukan kasasi demi kepentingan hukum. Terpidana diberi kesempatan untuk melakukan upaya hukum luar biasa yaitu peninjauan kembali. Selain itu kasasi demi kepentingan hukum tidak boleh merugikan pihak yang berkepentingan yaitu pihak terpidana.

\section{B.2.2. Peninjauan Kembali}

Upaya hukum luar biasa peninjauan kembali diatur dalam Pasal 263 sampai dengan Pasal 269 KUHAP. Putusan yang dapat dimohonkan peninjauan kembali adalah semua putusan pengadilan yang telah memperoleh kekuatan hukum tetap termasuk putusan Mahkamah Agung. Dalam kasasi demi kepentingan hukum yang dapat diajukan adalah terhadap semua putusan pengadilan kecuali terhadap putusan Mahkamah Agung, tetapi dalam peninjauan kembali putusan Mahkamah Agung dapat dikoreksi. Hal ini diatur dalam Pasal 263 ayat (1) KUHAP yang menyatakan bahwa terhadap putusan pengadilan yang telah memperoleh kekuatan hukum tetap, kecuali putusan bebas atau lepas dari segala tuntutan hukum, terpidana atau ahli warisnya dapat mengajukan permintaan peninjauan kembali kepada Mahkamah Agung. Dalam pengajuan permohonan peninjauan kembali tidak diatur mengenai tenggang waktu, sebagaimana diatur dalam Pasal 264 ayat (3) KUHAP bahwa permintaan peninjauan kembali tidak dibatasi dengan suatu jangka waktu.

Alasan untuk mengajukan peninjauan kembali adalah karena adanya keadaan baru, dalam pelbagai putusan terdapat saling pertentangan dan terdapat kekhilafan yang nyata dalam putusan. Alasan peninjauan kembali ini dituangkan dalam Pasal 263 ayat (2) yang menyatakan:

a. apabila terdapat keadaan baru yang menimbulkan dugaan kuat, bahwa jika keadaan itu sudah diketahui pada waktu sidang masih berlangsung, hasilnya akan berupa putusan bebas atau putusan lepas dari segala tuntutan hukum atau tuntutan penuntut umum tidak dapat diterima atau terhadap perkara itu diterapkan ketentuan pidana yang lebih ringan;

b. apabila dalam pelbagai putusan terdapat pernyataan bahwa sesuatu telah terbukti, akan tetapi hal atau keadaan sebagai dasar dan alasan putusan yang dinyatakan telah terbukti itu, ternyata telah bertentangan satu dengan yang lain; 
c. apabila putusan itu dengan jelas memperlihatkan suatu kekhiIafan hakim atau suatu kekeliruan yang nyata.

Adanya novum atau keadaan baru, yang dapat menimbulkan dugaan kuat:

1) Jika seandainya keadaan baru itu diketahui atau ditemukan dan dikemukakan pada waktu sidang berlangsung, dapat menjadi faktor dan alasan untuk menjatuhkan putusan bebas atau putusan lepas dari segala tuntutan hukum, atau;

2) Keadaan baru itu jika ditemukan dan diketahui pada waktu sidang berlangsung, dapat menjadi alasan dan faktor untuk putusan yang menyatakan tuntutan penuntut umum tidak dapat diterima, atau;

3) Dapat dijadikan alasan dan faktor untuk menjatuhkan putusan dengan menerapkan ketentuan pidana yang lebih ringan. ${ }^{5}$

Dalam hal pelbagai putusan terdapat saling pertentangan, hal ini dapat terjadi apabila sesuatu telah terbukti dan dijadikan alasan untuk menjatuhkan putusan tetapi dalam perkara lain keadaan yang dinyatakan terbukti tersebut saling bertentangan antara putusan yang satu dengan putusan lainnya. Kekhilafan hakim atau kekeliruan hakim dapat terjadi, karena tidak dipungkiri bahwa hakim adalah manusia yang juga tidak lepas dari kekhilafan ataupun kekeliruan.

Upaya hukum peninjauan kembali diajukan oleh terpidana atau ahli warisnya sebagaimana dicantumkan dalam Pasal 263 ayat (1) KUHAP. Dengan demikian jaksa penuntut umum tidak diperbolehkan mengajukan peninjauan kembali. Sebabnya undang-undang tidak memberi hak kepada penuntut umum karena upaya hukum ini bertujuan untuk melindungi kepentingan terpidana. $^{6}$

Putusan dalam peninjauan kembali, Pasal 266 ayat (1) KUHAP menyatakan bahwa apabila permintaan peninjauan kembali tidak sesuai dengan alasan-alasan yang ditentukan, maka Mahkamah Agung menyatakan bahwa permintaan peninjauan kembali tidak dapat diterima dengan disertai dasar alasannya. Apabila Mahkamah Agung berpendapat bahwa permintaan peninjauan kembali dapat diterima untuk diperiksa, maka apabila Mahkamah Agung tidak membenarkan alasan pemohon, Mahkamah Agung menolak permintaan peninjauan kembali dengan menetapkan bahwa putusan yang dimintakan peninjauan kembali itu tetap berlaku disertai dasar pertimbangannya. Selanjutnya apabila Mahkarnah Agung membenarkan alasan pemohon, Mahkamah
Agung membatalkan putusan yang dimintakan peninjauan kembali itu dan menjatuhkan putusan yang dapat berupa putusan bebas, putusan lepas dari segala tuntutan hukum, putusan tidak dapat menerima tuntutan penuntut umum, atau putusan dengan menerapkan ketentuan pidana yang lebih ringan. Hal tersebut sebagaimana diatur dalam Pasal 266 ayat (2) KUHAP. Telah dijelaskan sebelumnya bahwa peninjauan kembali adalah untuk melindungi kepentingan terpidana, sehingga pidana yang dijatuhkan dalam putusan peninjauan kembali tidak boleh melebihi pidana yang telah dijatuhkan dalam putusan sebelumnya atau putusan semula.

Selanjutnya upaya hukum peninjauan kembali, hanya dapat dilakukan satu kali sebagaimana ditentukan Pasal 268 ayat (3) KUHAP. Terhadap ketentuan Pasal 268 ayat (3) tersebut telah diajukan uji materi dan telah diputus MK dengan Putusan No. 34/PUU-XI/2013. Undang-Undang No.48 Tahun 2009 tentang Kekuasaan Kehakiman, juga mengatur mengenai upaya hukum peninjauan kembali sebagaimana diatur dalam Pasal 24 yang menyebutkan :

(1) Terhadap putusan pengadilan yang telah memperoleh kekuatan hukum tetap, pihakpihak yang bersangkutan dapat mengajukan peninjauan kembali kepada Mahkamah Agung, apabila terdapat hal atau keadaan tertentu yang ditentukan dalam undangundang.

(2) Terhadap putusan peninjauan kembali tidak dapat dilakukan peninjauan kembali.

Selain dalam Undang-Undang Kekuasaan Kehakiman, peninjauan kembali juga diatur dalam Undang-Undang No. 14 Tahun 1985 tentang Mahkamah Agung sebagaimana telah diubah dengan Undang-Undang No. 5 Tahun 2004 tentang Perubahan atas Undang-Undang Nomor 14 Tahun 1985 tentang Mahkamah Agung sebagaimana diubah dengan Undang-Undang No.3 Tahun 2009 tentang Perubahan Kedua Atas Undang-Undang No.14 Tahun 1985 tentang Mahkamah Agung, Pasal 66 menyebutkan:

(1) Permohonan peninjauan kembali dapat diajukan hanya 1 (satu) kali.

(2) Permohonan peninjauan kembali tidak menangguhkan atau menghentikan pelaksanaan putusan Pengadilan.

(3) Permohonan peninjauan kembali dapat dicabut selama belum diputus, dan dalam hal sudah dicabut permohonan peninjauan kembali itu tidak dapat diajukan lagi.

\footnotetext{
${ }^{5}$ Harahap, op. cit., halaman 619.

${ }^{6} \mathrm{Ibid}$, halaman 616.
} 


\section{METODE PENELITIAN}

\section{A. Metode Pendekatan}

Metode pendekatan yang digunakan dalam penelitian mengenai upaya hukum peninjauan kembali dalam perkara pidana pasca putusan Mahkamah Konstitusi ini adalah pendekatan yuridis normatif. Penelitian hukum normatif adalah penelitian hukum yang meletakkan hukum sebagai sebuah bangunan sistem norma. Sistem norma yang dimaksud adalah mengenai asas-asas, norma, kaidah dari peraturan perundang-undangan, putusan pengadilan, perjanjian serta doktrin (ajaran). ${ }^{7}$ Dalam penelitian ini, pendekatan yuridis normatif dilakukan dengan bertumpu pada asasasas hukum dan kaidah-kaidah atau norma-norma hukum positif yang berkaitan dengan upaya hukum peninjauan kembali dalam perkara pidana dan putusan Mahkamah Konstitusi yang memutus mengenai peninjauan kembali.

\section{B. Spesifikasi Penelitian}

Penelitian ini dilakukan secara deskriptif analitis yang merupakan cara pemecahan masalah penelitian yang dilakukan dengan cara menggambarkan atau mendeskripsikan obyek yang diteliti yaitu peraturan-peraturan yang berkaitan dengan upaya hukum peninjauan kembali yang dikhususkan pada perkara pidana pasca putusan Mahkamah Konstitusi, kemudian dilakukan analisis terhadap obyek dan data telah yang diperoleh tersebut. Hal itu dimaksudkan untuk memberikan gambaran dan analisis mengenai upaya hukum peninjauan kembali dalam perkara pidana pasca putusan Mahkamah Konstitusi.

\section{Teknik Pengumpulan Data}

Sumber data utama yang digunakan dalam penelitian ini adalah data sekunder dengan menggunakan teknik pengumpulan data melalui studi kepustakaan yaitu memilih dan mengelompokkan aturan-aturan atau ketentuan-ketentuan hukum mengenai upaya hukum peninjauan kembali dalam pekara pidana pasca putusan Mahkamah Konstitusi. Data yang akan dikumpulkan berbentuk dokumen atau tulisan berdasarkan penelusuran peraturan hukum, dokumen-dokumen maupun literatur-literatur ilmiah, dengan tujuan untuk memperoleh data sekunder sebagai data utama.

Data sekunder memiliki ciri-ciri umum sebagai berikut :

${ }^{7}$ Mukti Fajar ND dan Yulianto Achma, Dualisme Penelitian Hukum Normatif dan Empiris (Yogyakarta: Pustaka Pelajar,2013), halaman 34.
(1) Data sekunder pada umumnya ada dalam keadaan siap terbuat (ready-made).

(2) Bentuk maupun isi data sekunder telah dibentuk dan diisi oleh peneliti-peneliti pendahulu.

(3) Data sekunder dapat diperoleh tanpa terikat atau dibatasi oleh waktu dan tempat.

Bahan hukum primer dalam penelitian ini meliputi peraturan-peraturan yang mengatur mengenai upaya hukum peninjauan kembali dalam perkara pidana dan Mahkamah Konstitusi, di antaranya Undang-Undang No.8 Tahun 1981, Undang-Undang No. 48 Tahun 2009, UndangUndang Nomor 24 Tahun 2003 sebagaimana telah diubah dengan Undang-Undang Nomor 8 Tahun 2011 dan lain-lain. Untuk bahan hukum sekunder meliputi tulisan-tulisan ilmiah dari para ahli mengenai upaya hukum peninjauan kembali dalam perkara pidana pasca Mahkamah Konstitusi dan bahan hukum tersier yang berupa bahan-bahan yang bersifat menunjang bahan hukum primer dan sekunder seperti kamus hukum, kamus bahasa, artikel-artikel pada surat kabar, majalah serta internet mengenai upaya hukum peninjauan kembali dalam perkara pidana pasca Mahkamah Konstitusi.

\section{Analisis Data}

Metode analisis data yang akan dilakukan adalah secara kualitatif normatif yakni dengan memberikan gambaran secara khusus berdasarkan data yang dikumpulkan. Analisis dilakukan atas data yang telah ada. Berdasarkan data yang telah masuk dan diolah sedemikian rupa dengan meneliti kembali, sehingga analisis dapat diuji kebenarannya. Analisis data ini dilakukan peneliti secara cermat dengan berpedoman pada tipe dan tujuan dari penelitian yang dilakukan. ${ }^{9}$ Kualitatif berarti menekankan pada penyelesaian terhadap data yang telah diperoleh atau bersumber pada kebenaran dari hasil observasi penelitian. Analisis secara kualitatif normatif yaitu dengan cara melakukan langkah-langkah kategorisasi, penafsiran, korelasi dan perbandingan terhadap bahan-bahan hukum dan peraturan hukum mengenai mengenai upaya hukum peninjauan kembali dalam perkara pidana pasca Mahkamah Konstitusi. Analisis kualitatif tersebut dilakukan dengan penalaran berdasarkan logika sehingga dapat menarik kesimpulan yang

${ }^{8}$ Soeryono Soekanto dan Sri Mamudji, Penelitian Hukum Normatif Suatu Tinjauan Singkat, (Jakarta: PT Radja Grafindo Persada, 2007), halaman24.

${ }^{9}$ Ronny Hanitijo Soemitro. Metodologi Penelitian Hukum dan Jurimetri.(Jakarta: Ghalia Indonesia, 1998), halaman 35. 
logis, yang selanjutnya disusun dalam bentuk sebuah laporan penelitian.

\section{HASIL DAN PEMBAHASAN}

A. Dengan adanya Putusan MK No. 34/PUU$\mathrm{XI} / 2013$ yang memperbolehkan peninjauan kembali lebih dari satu kali dalam perkara pidana dapat memenuhi nilai keadilan dan kepastian hukum.

Hukum pada dasarnya dibuat untuk membantu masyarakat dalam kehidupan sehari-hari, untuk menyelesaikan kepentingan-kepentingan dalam hidup bermasyarakat sehingga dapat diperoleh keadilan dan kepastian dalam hubungan satu dengan yang lain. Hukum juga diharapkan mempunyai nilai guna untuk menciptakan keteraturan dalam bermasyarakat. Hukum dituntut untuk memenuhi berbagai karya dan oleh Radbruch ketiga-tiganya disebut sebagai nilai dasar dari hukum. Ketiga nilai dasar tersebut adalah keadilan, kegunaan (Zweckmaszigkeit) dan kepastian hukum. ${ }^{10}$ Dalam suatu peraturan, dapat dikatakan sulit untuk memenuhi ketiga nilai dasar tersebut. Hal ini disebabkan adanya potensi untuk saling bertentangan antara nilai dasar yang satu dengan yang lain.

Upaya hukum luar biasa peninjauan kembali merupakan hak terpidana yang dilakukan setelah putusan mempunyai kekuatan hukum tetap. Peninjauan kembali ini merupakan wewenang MA sehingga dalam kapasitas ketika memeriksa peninjauan kembali menjadi sekaligus selain iudex iuris juga sebagai iudex facti. ${ }^{11}$ Adanya Putusan MK No. 34/PUU-XI/2013, yang memperbolehkan peninjauan kembali lebih dari satu kali, membuka kesempatan bagi terpidana untuk memperoleh keadilan, selain itu juga membuka jalan diperolehnya kebenaran materiil dan kepastian hukum.

Upaya hukum luar biasa bertujuan untuk menemukan keadilan dan kebenaran materiil. Keadilan tidak dapat dibatasi oleh waktu atau ketentuan formalitas yang membatasi upaya hukum luar biasa (PK) hanya dapat diajukan satu kali. Mungkin saja setelah diajukannya PK dan diputus, ada keadaan baru (novum)

10 Satjipto Rahardjo, Ilmu Hukum (Bandung: PT Citra Aditya Bakti, 2000), halaman 19.

${ }^{11}$ Luhut M.P. Pangaribuan, "Peninjauan Kembali("PK") Sebagai Upaya Hukum Lur Biasa: Suatu Catatan Hukum Untuk Prospeksi" (Seminar Nasional diselenggarakan oleh Program Doktor Ilmu Hukum Fakultas Hukum Unnisula Semarang, 31 Januari 2015). yang substansial baru ditemukan saat PK sebelumnya belum ditemukan. ${ }^{12}$

MK berpendapat bahwa untuk memperoleh keadilan dan kebenaran yang sesungguhnya, sudah seharusnya tidak dibatasi dengan waktu maupun dibatasi dengan prosedur peninjauan kembali hanya satu kali. Dalam hukum acara pidana, kebenaran yang hendak dicari adalah kebenaran materiil (kebenaran yang sesungguhnya) sehingga untuk memperoleh kebenaran tersebut sudah selayaknya untuk tidak dibatasi oleh formalitas yang akan menghambat dalam rangka pencarian kebenaran materiil itu sendiri.

Putusan MK No. 34/PUU-XI/2013, di antaranya adalah berkaitan dengan hak asasi manusia terutama kewajiban negara untuk memberikan perlindungan, pemajuan, penegakan, dan pemenuhan terhadap HAM. KUHAP merupakan salah satu sarana dalam rangka mewujudkan hak asasi manusia (dalam peradilan pidana), sehingga dalam proses peradilan pidana sudah seharusnya dilakukan untuk memperoleh kepastian hukum yang adil.

Menurut Mahkamah adanya pembatasan hak dan kebebasan yang diatur UU seperti diatur Pasal 28J ayat (2) UUD 1945, tidak dapat diterapkan membatasi pengajuan PK hanya satu kali. Sebab, pengajuan PK perkara pidana sangat terkait dengan HAM yang paling mendasar menyangkut kebebasan dan kehidupan manusia. ${ }^{13}$

Kepastian hukum yang dijamin dalam KUHAP sebaiknya dipahami dengan tidak boleh mengesampingkan nilai keadilan dan kebenaran materiil yang menjadi tujuan dari pemeriksaan suatu tindak pidana, sehingga untuk ketentuan peninjauan kembali dalam perkara pidana sudah seharusnya diperbolehkan lebih dari satu kali. Menurut penulis, peninjauan kembali lebih dari satu kali, lebih dapat menjamin kepastian hukum bagi pencari keadilan (terpidana) dengan pemahaman bahwa terpidana memperoleh kesempatan untuk mencari dan membuktikan kebenaran materiil, sehingga diperoleh kepastian hukum yang berkeadilan. Selain memberi kepastian hukum, peninjauan kembali lebih dari satu kali juga dapat memberikan kemanfaatan dan keadilan sebagaimana tujuan yang hendak dicapai dalam hukum acara pidana. Hukum mempunyai

\footnotetext{
${ }^{12}$ Agus Sahbani, "MK Batalkan Aturan PK Hanya Sekali" (http:www.hukumonline,com/ berita/baca/lt53187f2d25845, diakses 3 Februari 2015).

${ }^{13}$ Ibid.
} 
kegunaan atau kemanfaatan bagi masyarakat dan tujuan dari hukum khususnya hukum acara pidana tersebut menjadi terpenuhi. Menurut Gayus Lumbuun, bahwa ini (putusan MK) merupakan putusan yang arif dan bijaksana dalam memahami dengan sungguh-sungguh tentang tujuan hukum yang harus memberikan kepastian hukum, kemanfaatan dan keadilan. ${ }^{14}$ Upaya hukum luar biasa bertujuan menemukan keadilan dan kebenaran materiel tanpa dibatasi oleh limitasi waktu. Adanya pembatasan peninjauan kembali hanya satu kali telah secara nyata membatasi pencarian keadilan (oleh terpidana) sehingga bertentangan dengan asas keadilan yang dijunjung tinggi oleh pelaku kekuasaan kehakiman berdasarkan Pasal 24 UUD 1945. Dalam hal ini kepastian hukum yang dicari adalah kepastian hukum yang berkeadilan yaitu kepastian hukum yang tidak mengabaikan nilai keadilan. Apabila keadilan prosedural mengabaikan atau mengorbankan keadilan substansial, maka yang lebih didahulukan adalah keadilan substansial. Terlebih Mahkamah Konstitusi menganut prinsip hukum progresif yang mengutamakan keadilan substantif daripada keadilan prosedural, tetapi hal ini jangan dimaknai bahwa MK mengabaikan keadilan prosedural. Manakala keadilan prosedural menyandera keadilan substansial, maka keadilan substansial yang didahulukan. ${ }^{15}$

Dalam hukum progresif yang merupakan gagasan dari Satjipto Rahardjo, berusaha menitikberatkan pada kepentingan manusia terhadap produk hukum. Dengan demikian, manusia dikomposisikan pada sebuah titik sentral hukum, sehingga berarti; kebahagiaannya, kesejahteraannya, rasa keadilannya dan sebagainya menjadi pusat dari kepedulian hukum. ${ }^{16}$ Apapun yang dilakukan oleh hukum, ia tak dapat mengabaikan, bahwa manusia yang berada dipusatnya, sehingga kita berpaham 'hukum untuk manusia' dan bukan

\footnotetext{
${ }^{14}$ Anggi Kusumadewi, Syahrul Ansyari, “ MA: MK Buat Putusan Bijaksana Soal Peninjauan Kembali",(http://nasional.news.viva.co.id/news/rea d/486796-ma--mk-buat-putusan-bijaksana-soal peninjauan-kembali, diakses 3 Februari 2015).

${ }^{15}$ Arief Hidayat, "Konstruksi Ideal Pelaksanaan Peninjauan Kembali Berdasarkan Putusan Mahkamah Konstitusi”, (Seminar Nasional diselenggarakan oleh Program Doktor Ilmu Hukum Fakultas Hukum Unnisula Semarang, 31 Januari 2015).

${ }^{16}$ I Gede A.B Wiranata, "Hukum Progresif Versus Pembangunan Hukum (Sebuah Pencarian Model)" dalam Satjipto Rahardjo, Membedah Hukum Progresif, (Jakarta: Kompas, 2006), halaman 265 .
}

sebaliknya. ${ }^{17}$ Apabila dikaitkan dengan produk perundang-undangan mengenai upaya hukum peninjauan kembali, maka sudah selayaknya pengaturan kembali atau pun harmonisasi peraturan mengenai upaya hukum peninjauan kembali dititikberatkan kepada kepentingan manusia khususnya untuk memenuhi nilai keadilan dengan tidak mengabaikan nilai kepastian hukum.

\section{B. Pengaturan mengenai peninjauan kembali sebagai implementasi Putusan MK No. 34/PUU-XI/2013 agar asas kepastian hukum dan asas litis finiri oportet (setiap perkara harus ada akhirnya) akan terpenuhi.}

Sebelum adanya pengajuan uji materi Pasal 268 ayat (3) KUHAP oleh Antasari Azhar, MA telah mengeluarkan Surat Edaran MA No.10 Tahun 2009 tentang Pengajuan Permohonan Peninjauan Kembali, yang pada intinya bahwa untuk permohonan peninjauan kembali dalam perkara yang sama baik perkara perdata maupun pidana adalah bertentangan dengan undangundang. Apabila ada permohonan peninjauan kembali yang kedua dan seterusnya sesuai dengan 45 A Undang-Undang No.14 Tahun 1985 tentang Mahkamah Agung sebagaimana telah diubah dengan Undang-Undang No.5 Tahun 2004 dan perubahan kedua dengan Undang-Undang No.3 Tahun 2009 (Undang-Undang MA), agar dengan Penetapan Ketua Pengadilan Tingkat Pertama, permohonan tersebut dinyatakan tidak dapat diterima dan berkasnya tidak perlu dikirim ke MA. Dengan demikian dapat dikatakan bahwa untuk permohonan peninjauan kembali dengan perkara yang sama, tidak dapat dilakukan untuk kedua kali dan seterusnya.

Selanjutnya dalam Surat Edaran MA No.10 Tahun 2009 tersebut juga diatur bahwa apabila dalam suatu obyek perkara terdapat dua atau lebih putusan peninjauan kembali yang bertentangan satu dengan yang lainnya baik dalam perkara perdata maupun perkara pidana, dan di antaranya ada yang diajukan permohonan peninjauan kembali agar permohonan peninjauan kembali tersebut diterima oleh pengadilan tingkat pertama dan berkasnya dikirim ke MA. Dari ketentuan surat edaran tersebut dapat dikatakan bahwa untuk dua atau lebih putusan peninjauan kembali terhadap perkara yang sama, dimana putusannya bertentangan satu dengan yang lain, maka dapat diajukan lagi permohonan peninjauan kembali. Dengan demikian pengaturan mengenai permohonan peninjauan kembali lebih dari satu

${ }^{17}$ Satjipto Rahardjo, Sisi Lain dari Hukum di Indonesia, (Jakarta: Kompas, 2006), halaman34. 
kali terhadap perkara yang sama, sebelumnya sudah diatur oleh MA melalui Surat Edaran MA No.10 Tahun 2009 tentang Pengajuan Permohonan Peninjauan Kembali.

Adanya Surat Edaran MA No.07 Tahun 2014 pada tanggal 31 Desember 2014 tentang Pengajuan Permohonan Peninjauan Kembali dalam Perkara Pidana, telah menimbulkan perdebatan baik dari kalangan akademisi, praktisi maupun masyarakat pada umumnya. Berdasarkan Surat Edaran No.07 Tahun 2014 tersebut, bahwa untuk permohonan peninjauan kembali dalam perkara pidana hanya diperbolehkan satu kali. Dengan dinyatakannya Pasal 268 ayat (3) KUHAP tidak mempunyai kekuatan hukum mengikat oleh putusan Mahkamah Konstitusi No. 34/PUU-XI/2013, tidak serta merta menghapus norma hukum yang mengatur permohonan peninjauan kembali yang diatur oleh Undang-Undang No.48 Tahun 2009 tentang Kekuasaan Kehakiman Pasal 24 ayat (2) dan Undang-Undang No.14 Tahun 1985 tentang Mahkamah Agung sebagaimana telah diubah dengan Undang-Undang No.5 Tahun 2004 dan perubahan kedua dengan Undang-Undang No.3 Tahun 2009 Pasal 66 ayat (1). Dengan demikian untuk permohonan peninjauan kembali dalam perkara pidana hanya diperbolehkan satu kali, oleh MA hal ini didasarkan pada ketentuan yang ada pada Undang-Undang Kekuasaan Kehakiman dan Undang-Undang MA.

Sebelum adanya Surat Edaran MA No.07 Tahun 2014 tersebut, sudah ada kesepakatan upaya hukum peninjauan kembali hanya boleh dua kali yang telah diputuskan dalam rapat pleno kamar pidana. Mahkamah Agung menyepakati pengajuan upaya hukum peninjauan kembali untuk perkara pidana hanya bisa dilakukan dua kali. Meski demikian, MA belum memutuskan instrumen apa yang akan digunakan untuk mengatur ketentuan tersebut. ${ }^{18}$

Pasca dikeluarkannya Putusan Mahkamah Konstitusi No. 34/PUU-XI/2013, sudah seharusnya dilakukan harmonisasi terhadap ketentuan permohonan peninjauan kembali dalam perkara pidana agar tidak menimbulkan kekosongan hukum. Sebaiknya MA dalam mengeluarkan surat edaran, tidak bertentangan dengan apa yang telah diputuskan oleh Mahkamah Konstitusi sehingga tidak terjadi ketidaksinkronan.

18 "MA Putuskan PK Hanya Dibolehkan Dua Kali, Eksekusi Mati Dapat Segera Dilakukan" (http://nasional.kompas.com/read/2014/12/29/1502 3451/MA.Putuskan.PK.Hanya.Dibolehkan.Dua.Ka $\underline{\text { li.Eksekusi.Mati.Dapat.Segera.Dilakukan, diakses }}$ 3 Pebruari 2015).
Diperbolehkannya peninjauan kembali lebih dari satu kali berdasarkan Putusan Mahkamah Konstitusi No. 34/PUU-XI/2013 , bisa ditafsirkan dapat dilakukan kedua, ketiga dan seterusnya. Tetapi hal ini menjadikan asas litis finiri oportet yang menegaskan bahwa setiap perkara harus ada akhirnya, menjadi tidak terpenuhi. Dengan demikian untuk memenuhi asas litis finiri oportet, perlu dilakukan pembatasan dalam hal kuantitas pengajuan permohonan peninjauan kembali. Untuk upaya hukum peninjauan kembali dalam perkara pidana dari segi kuantitas sebaiknya dapat dilakukan dua kali, hal ini dilakukan untuk mencapai keseimbangan antara nilai kepastian hukum dan nilai keadilan sehingga diperoleh kepastian hukum yang berkeadilan. Di satu pihak peninjauan kembali dapat dilakukan lebih dari satu kali untuk mencari kebenaran materiil dan memenuhi nilai keadilan. Di lain pihak adanya pembatasan permohonan peninjauan kembali yang diajukan dua kali adalah untuk menjamin kepastian hukum, sehingga nilai kemanfaatan, keadilan dan kepastian hukum dapat terpenuhi.

Ditentukannya peninjauan kembali dapat dilakukan dua kali, dengan alasan bahwa apabila peninjauan kembali dilakukan tiga kali atau lebih tentunya berkaitan dengan jangka waktu yaitu akan memerlukan waktu yang tidak menentu karena belum ada pembatasan waktu untuk dilakukannya peninjauan kembali. Apabila dilakukan pembatasan waktu untuk peninjauan kembali, tentunya ini berkaitan dengan nilai keadilan dan hak asasi manusia terutama dalam hal ini hak asasi terpidana. Selain itu juga berkaitan dengan pelaksanaan putusan pengadilan, meskipun dalam Pasal 268 ayat (1) KUHAP menentukan bahwa permintaan peninjauan kembali atas suatu putusan tidak menangguhkan maupun menghentikan pelaksanaan dari putusan pengadilan yang telah berkekuatan hukum tetap.

\section{SIMPULAN}

\section{Simpulan :}

1. Upaya hukum luar biasa bertujuan menemukan keadilan dan kebenaran materiel tanpa dibatasi oleh limitasi waktu. Dengan demikian adanya pembatasan peninjauan kembali hanya satu kali telah secara nyata membatasi pencarian keadilan (oleh terpidana) sehingga bertentangan dengan asas keadilan yang dijunjung tinggi oleh pelaku kekuasaan kehakiman berdasarkan Pasal 24 UUD 1945. Dalam hal ini kepastian hukum yang dicari adalah kepastian hukum yang berkeadilan yaitu kepastian hukum yang tidak mengabaikan nilai keadilan. Putusan MK No. 
34/PUU-XI/2013, yang menyatakan bahwa Pasal 268 ayat (3) Undang-Undang Nomor 8 Tahun 1981 tentang Hukum Acara Pidana bertentangan dengan Undang-Undang Dasar Negara Republik Indonesia tahun 1945 dan tidak mempunyai kekuatan mengikat, dapat memenuhi kepastian hukum tanpa mengabaikan nilai keadilan. Hal ini dapat dilihat dari pihak kepentingan terpidana yang mana dengan diperbolehkannya peninjauan kembali dalam perkara pidana lebih dari satu kali, memberikan kesempatan untuk memper-oleh kebenaran materiil dan keadilan sehingga dapat diperoleh kepastian hukum yang berkeadilan bagi terpidana mengenai perkara yang dihadapi.

2. Diperbolehkannya peninjauan kembali lebih dari satu kali pasca Putusan MK No. 34/PUU$\mathrm{XI} / 2013$, bisa ditafsirkan dapat dilakukan kedua, ketiga dan seterusnya. Tetapi hal ini menjadikan asas litis finiri oportet yang menegaskan bahwa setiap perkara harus ada akhirnya, menjadi tidak terpenuhi. Dengan demikian sebagai implementasi Putusan MK No. 34/PUU-XI/2013 agar asas kepastian hukum dan asas litis finiri oportet terpenuhi, perlu dilakukan pengaturan mengenai pembatasan dalam hal kuantitas pengajuan permohonan peninjauan kembali. Bahwa untuk upaya hukum peninjauan kembali dalam perkara pidana dari segi kuantitas dapat sebaiknya dilakukan dua kali, hal ini dilakukan untuk mencapai kepastian hukum yang berkeadilan. Di satu pihak peninjauan kembali dapat dilakukan lebih dari satu kali untuk mencari kebenaran materiil dan memenuhi nilai keadilan. Di lain pihak adanya pembatasan permohonan peninjauan kembali yang boleh dilakukan dua kali adalah untuk menjamin kepastian hukum, sehingga nilai kemanfaatan, keadilan dan kepastian hukum dapat terpenuhi.

\section{DAFTAR PUSTAKA}

\section{Buku:}

Fajar Mukti ND dan Yulianto Achmad, Dualisme Penelitian Hukum Normatif dan Empiris, Yogyakarta: Pustaka Pelajar,2013.

Rahardjo, Satjipto, Ilmu Hukum, Bandung: PT Citra Aditya Bakti, 2000;

Jakarta: Kompas, 2006;
----, Sisi Lain dari Hukum di

Indonesia, Jakarta: Kompas, 2006;

Soemitro, Ronny Hanitijo, Metodologi Penelitian Hukum Dan Jurimetri, Jakarta: Ghalia Indonesia, 1998.

Soekanto, Soerjono dan Sri Mamudji, Penelitian Hukum Normatif (suatu Tinjauan Singkat), Jakarta : Rajawali Press, 2007.

Yahya, M Harahap, Pembahasan Permasalahan dan Penerapan KUHAP : Pemeriksaan Sidang Pengadilan, Banding, Kasasi, dan Peninjauan Kembali , Jakarta: Sinar Grafika, 2009.

Zulkarnain, Praktik Peradilan Pidana, Malang: Setara Press, 2013.

\section{Makalah :}

Pangaribuan, Luhut M.P., "Peninjauan Kembali("PK") Sebagai Upaya Hukum Luar Biasa: Suatu Catatan Hukum Untuk Prospeksi" (Seminar Nasional diselenggarakan oleh Program Doktor Ilmu Hukum Fakultas Hukum Unnisula Semarang, 31 Januari 2015);

Hidayat, Arief, "Konstruksi Ideal Pelaksanaan Peninjauan Kembali Berdasarkan Putusan Mahkamah Konstitusi”, (Seminar Nasional diselenggarakan oleh Program Doktor Ilmu Hukum Fakultas Hukum Unnisula Semarang, 31 Januari 2015).

\section{Peraturan :}

Undang-Undang Dasar Negara Republik Indonesia Tahun 1945;

Putusan MK No. 114/PUU-X/2012;

Putusan MK No. 34/PUU-XI/2013;

Undang-Undang No.8 Tahun 1981 tentang Hukum Acara Pidana;

Undang-Undang No. 14 Tahun 1985 tentang Mahkamah Agung sebagaimana telah diubah dengan Undang-Undang No. 5 Tahun 2004 tentang Perubahan atas Undang-Undang Nomor 14 Tahun 1985 tentang Mahkamah Agung sebagaimana diubah dengan Undang-Undang No.3 Tahun 2009 tentang Perubahan Kedua Atas 
Undang-Undang No.14 Tahun 1985 tentang Mahkamah Agung;

Undang-Undang Nomor 24 Tahun 2003 tentang Mahkamah Konstitusi sebagaimana telah diubah dengan Undang-Undang Nomor 8 Tahun 2011 tentang Perubahan Atas Undang-Undang Nomor 24 Tahun 2003 tentang Mahkamah Konstitusi;

Undang-Undang No.48 tahun 2009 tentang Kekuasaan Kehakiman;

Undang-Undang No.12 Tahun 2011 tentang Pembentukan Peraturan PerundangUndangan;

Surat Edaran Mahkamah Agung RepubIik Indonesia Nomor 10 Tahun 2009 tentang Pengajuan Permohonan Peninjauan Kembali;

Surat Edaran Mahkamah Agung No.07 Tahun 2014 pada tanggal 31 Desember 2014 tentang Pengajuan Permohonan Peninjauan Kembali dalam Perkara Pidana.

Website :

Agus Sahbani, "MK Batalkan Aturan PK Hanya Sekali”

(http:www.hukumonline,com/berita/baca/lt 53187f2d25845, diakses 3 Februari 2015).

Anggi Kusumadewi, Syahrul Ansyari, “MA: MK Buat Putusan Bijaksana Soal Peninjauan Kembali",

(http://nasional.news.viva.co.id/news/read/4 86796-ma--mk-buat-putusan-bijaksana-soal peninjauan-kembali, diakses 3 Februari 2015).

"MA Putuskan PK Hanya Dibolehkan Dua Kali, Eksekusi Mati Dapat Segera Dilakukan" (http://nasional.kompas.com/read/2014/12/ 29/15023451/MA.Putuskan.PK.Hanya.Dib olehkan.Dua.Kali.Eksekusi.Mati.Dapat.Seg era.Dilakukan, diakses 3 Pebruari 2015). 